\title{
Perspectives on the Great Amazon Reef: Extension, Biodiversity, and Threats
}

\author{
Ronaldo B. Francini-Filho ${ }^{1}$, Nils E. Asp ${ }^{2}$, Eduardo Siegle ${ }^{3}$, John Hocevar ${ }^{4}$, \\ Kenneth Lowyck ${ }^{5}$, Nilo D'Avila ${ }^{6}$, Agnaldo A. Vasconcelos ${ }^{6}$, Ricardo Baitelo ${ }^{6}$, \\ Carlos E. Rezende ${ }^{7}$, Claudia Y. Omachi ${ }^{2}$, Cristiane C. Thompson ${ }^{8}$ and \\ Fabiano L. Thompson ${ }^{8 *}$
}

\section{OPEN ACCESS}

Edited by:

Christian Robert Voolstra,

King Abdullah University of Science and Technology, Saudi Arabia

Reviewed by:

Aldo Cróquer,

Simón Bolivar University, Venezuela John Everett Parkinson,

Oregon State University, United States

*Correspondence:

Fabiano L. Thompson fabianothompson1@gmail.com

Specialty section

This article was submitted to

Coral Reef Research,

a section of the journal Frontiers in Marine Science

Received: 30 October 2017 Accepted: 10 April 2018 Published: 23 April 2018

Citation:

Francini-Filho RB, Asp NE, Siegle E, Hocevar J, Lowyck K, D'Avila N, Vasconcelos $A A$, Baitelo $R$, Rezende CE, Omachi CY Thompson CC and Thompson FL (2018) Perspectives on the Great Amazon Reef: Extension, Biodiversity, and Threats. Front. Mar. Sci. 5:142. doi: 10.3389/fmars.2018.00142

\begin{abstract}
${ }^{1}$ Federal University of Paraiba, Rio Tinto, Brazil, ${ }^{2}$ Instituto de Estudos Costeiros, Federal University of Pará, Bragança, Brazil, ${ }^{3}$ Instituto Oceanográfico, University of São Paulo, São Paulo, Brazil, ${ }^{4}$ Greenpeace USA, Washington, DC, United States, ${ }^{5}$ Greenpeace France, Paris, France, ${ }^{6}$ Greenpeace Brazil, Rio de Janeiro, Brazil, ${ }^{7}$ Laboratório de Ciências Ambientais, Centro de Biociências e Biotecnologia, Universidade Estadual do Norte Fluminense, Campos dos Goytacazes, Brazil, ${ }^{8}$ Institute of Biology and COPPE, Federal University of Rio de Janeiro, Rio de Janeiro, Brazil
\end{abstract}

Here we provide a broad overview of the Great Amazon Reef System (GARS) based on the first-ever video surveys of the region. This footage supports four major hypotheses: (1) the GARS area may be six times larger than previously suggested (up to 56,000 $\mathrm{km}^{2}$ ); (2) the GARS may extend deeper than previously suggested (up to $220 \mathrm{~m}$ ); (3) the GARS is composed of a greater complexity and diversity of habitats than previously recognized (e.g., reef platforms, reef walls, rhodolith beds, and sponge bottoms); and (4) the GARS represents a useful system to test whether a deep corridor connects the Caribbean Sea to the Southwest Atlantic Ocean. We also call attention to the urgent need to adopt precautionary conservation measures to protect the region in the face of increasing threats from extractive oil and gas practices. With less than $5 \%$ of the potential area of the GARS surveyed so far, more research will be required to inform a systematic conservation planning approach and determine how best to establish a network of marine protected areas. Such planning will be required to reconcile extractive activities with effective biodiversity conservation in the GARS.

\footnotetext{
Keywords: mesophotic coral ecosystem, calcareous algae, submersibles, systematic conservation planning, oil and gas fields
}

Unprecedented submersible video surveys disclose unique features of the Great Amazon Reef System (GARS). Previous surveys of the GARS were performed exclusively with indirect sampling (i.e., fishing and dredging) (Collette and Ruetzler, 1977; Cordeiro et al., 2015; Moura et al., 2016). The definition of "reef" used here is the same one given by Collette and Ruetzler (1977) in their seminal work about the GARS: i.e., complex hard bottoms created by living organisms.

The first images of the GARS and associated communities were obtained here by using a double Deep Worker submarine (Nuytco, Canada; Earle, 2010) and a drop camera system in depths between 70 and $250 \mathrm{~m}$ in January-February 2017. The examination of over $20 \mathrm{~h}$ footage obtained by means of submarine and $15 \mathrm{~h}$ footage obtained by the drop camera, together with previous data (Moura et al., 2016), allowed us to advance the knowledge put forward here. Each of the submarine dives $(n=8)$ lasted about $4 \mathrm{~h}$ and covered a total linear distance of about $1 \mathrm{~km}$. Drop camera footages lasted $\sim 30-40 \mathrm{~min}$, and also covered a linear distance of about $1 \mathrm{~km}$ per dive. Main habitat types were visually recorded (Figure 1). 
The occurrence of a reef system off the Amazon River mouth was first hypothesized by Collette and Ruetzler (1977). According to these authors: "from the behavior of the trawl and from fathometer readings, we conclude that hard bottoms are abundant in this region." In addition, Cordeiro et al. (2015), based on the analysis of museum material, have speculated on the occurrence of rhodolith beds in the GARS by stating that "Although our data were insufficient to confirm the existence of rhodolith banks offshore of the Amazon River, some of the sampled corals analyzed were adhered to coralline algae." Finally, Moura et al. (2016) performed extensive trawling and side scan sonar surveys, confirming the GARS' existence and estimating its size at $9,500 \mathrm{~km}^{2}$. Results from the present survey suggest that the GARS is composed by typical mesophotic reefs (70-220 m depth) build mainly by living calcareous algae ("coralline algal frameworks," $c f$. Bosence, 1983), potentially covering an area of $\sim 56,000 \mathrm{~km}^{2}$ (Figure 2). Similar calcareous platforms covered by living calcareous algae were recorded at depths between 80 and $120 \mathrm{~m}$ in tropical and subtropical Eastern Australia (Davies et al., 2004). Calcareous algae are also major reef builders elsewhere in the Atlantic, being the dominant element of the reef framework in the Rocas Atoll (Gherardi and Bosence, 2001; Villas-Bôas et al., 2005) and in coral reefs of the Abrolhos Bank (Francini-Filho et al., 2013). Beside calcareous algae, scleractinian corals were also recorded during our surveys, with Madracis decactis being by far the most abundant one. Only areas shallower than $70 \mathrm{~m}$ were devoid of consolidated substrata and dominated by fine sand and/or mud bottoms.

The GARS extends much deeper than previously anticipated, with a clear gradient from its deepest portion ( $220 \mathrm{~m}$ depth), where laterite outcrops alternate with areas with nearly $100 \%$ of live coverage (mainly sponges, octocorals and black corals), to its shallowest portion $(\sim 70 \mathrm{~m})$, which is nearly completely covered by sand (Figures 1A-D). At depths of 80-100 m, marine snow might also temporarily cover rhodolith beds and algal frameworks (Figure 1B). Rhodolith beds and biogenic calcareous platforms are the dominant features in depths between 70 and $180 \mathrm{~m}$ (Figures 1C,E,H). This is the deepest limit of the lower mesophotic zone recorded so far, as mesophotic reefs are believed to occur only down to about $150 \mathrm{~m}$ (Lesser et al., 2009). Dominant organisms of the lower mesophotic zone of the GARS (180-220 m) were typical of reef communities, such as black corals, barrel sponges (Xetospongia muta) and butterfly fishes (Prognathodes spp.) (Rosa et al., 2016). The areas deeper than $220 \mathrm{~m}$ recorded during our surveys were dominated by sediments.

High bottom complexity and a great diversity of habitats were recorded at the GARS, including algal frameworks, rhodolith beds, laterite bottoms, as well as sponge, soft coral and black coral gardens (Figures 1A-D). A large reef wall was recorded in the outer shelf of the central sector of the GARS, with an average height of $80 \mathrm{~m}$ (115-195 $\mathrm{m}$ depth) and a mapped linear extension of at least $12 \mathrm{~km}$. Bordering the GARS on its shallowest portion, there were large sand wave fields (Figure 1A) which are indicative of strong currents and high hydrodynamic variations, with sand being eventually transported over the reef structure (Figure 1B).
Thus, a combination of suspended load from the Amazon River and intense sediment transport in the middle continental shelf seems to determine the upper boundary of the GARS.

High spatial turnover of species was noted within the reef, as well as between the GARS and adjacent regions (i.e., Caribbean and N/NE Brazil). This pattern is plausibly explained by both habitat heterogeneity and the formation of an ecotone between the two biogeographical provinces, i.e., Brazil and the Caribbean, with a clear faunal overlap. An example is the record made in this study for the Blue chromis Chromis cyanea, which was previously known to occur only in the Caribbean, reinforcing the hypothesis of a connection between South America and the South Caribbean through the GARS (Rocha, 2003; Floeter et al., 2008). In fact, first evidence for the occurrence of a mesophotic corridor connecting Brazil and the Caribbean were obtained by Collette and Ruetzler (1977), which described a "typical reef fish fauna" composed by 45 species in the mouth of the Amazon River in depths between 48 and $73 \mathrm{~m}$. Since then, several biogeographical studies have highlighted the existence of a biogeographical connection between Brazil and the Caribbean (Rocha, 2003; Floeter et al., 2008).

Several other interesting new observations of reef-associated organisms were made here. Aggregations of threatened and commercially important fishes (up to tens of individuals per dive), particularly large individuals $(>50 \mathrm{~cm}$ Total Length, as measured by a laser scale) of Lutjanus purpureus and Hyporthodus niveatus (Figure 1G) were clearly associated with fractures and crevices on carbonate platforms and crevices created by complex bottoms of laterite rock. Most fish aggregations were associated with cleaning stations, with juveniles of Spotfin hogfish Bodianus pulchelius and the Peppermint shrimp Lysmata grabhami acting as cleaners (Figure 1E). Beside cleaning stations, nests of the Sand tilefish Malacanthus plumieri, which are formed by aggregations of rhodoliths, were also inhabited by several species of fish and invertebrates (Figure 1F). Two herbivorous fish were recorded foraging in depths between 100 and $140 \mathrm{~m}$, the Agassiz's parrotfish Sparisoma frondosum and the Doctorfish Acanthurus chirurgus. Large barrens of sea urchins (unidentified Toxopneustidae) actively grazing macroalgae and leaving large paths of cleaned substrate, with thousands of meters in linear extension, were also recorded (Figure $\mathbf{1 H}$ ).

Light that reaches the sea bottom in the GARS is dependent on the sediment laden Amazon plume and clear tropical waters of the North Brazil Current (NBC). Our estimates for the diffuse light attenuation coefficient for photosynthetically available radiation (Kd $\mathrm{d}_{\mathrm{PAR}}$ ) for our sampling period (JanuaryFebruary 2017), based on MODIS aqua satellite images (Lee et al., 2002, 2005) ranged from 0.060 to $0.15 \mathrm{~m}^{-1}$ at diving/drop camera positions, with $0.01-19.3 \mu \mathrm{E} . \mathrm{m}^{-2} . \mathrm{s}^{-1}$ arriving at depths varying from 50 to $160 \mathrm{~m}$. Healthy rhodoliths may be found in light environment varying from 0.0015 to $32 \mu \mathrm{E} . \mathrm{m}^{-2} . \mathrm{s}^{-1}$ (Littler et al., 1986; Riul et al., 2008; Figueiredo et al., 2012), indicating that even though turbidity is relatively high in the GARS, light is not a limiting factor for its existence. The underwater images obtained here show that living calcareous algae are prevalent in depths of up to $180 \mathrm{~m}$ (Figures 1C,E,F,H). 

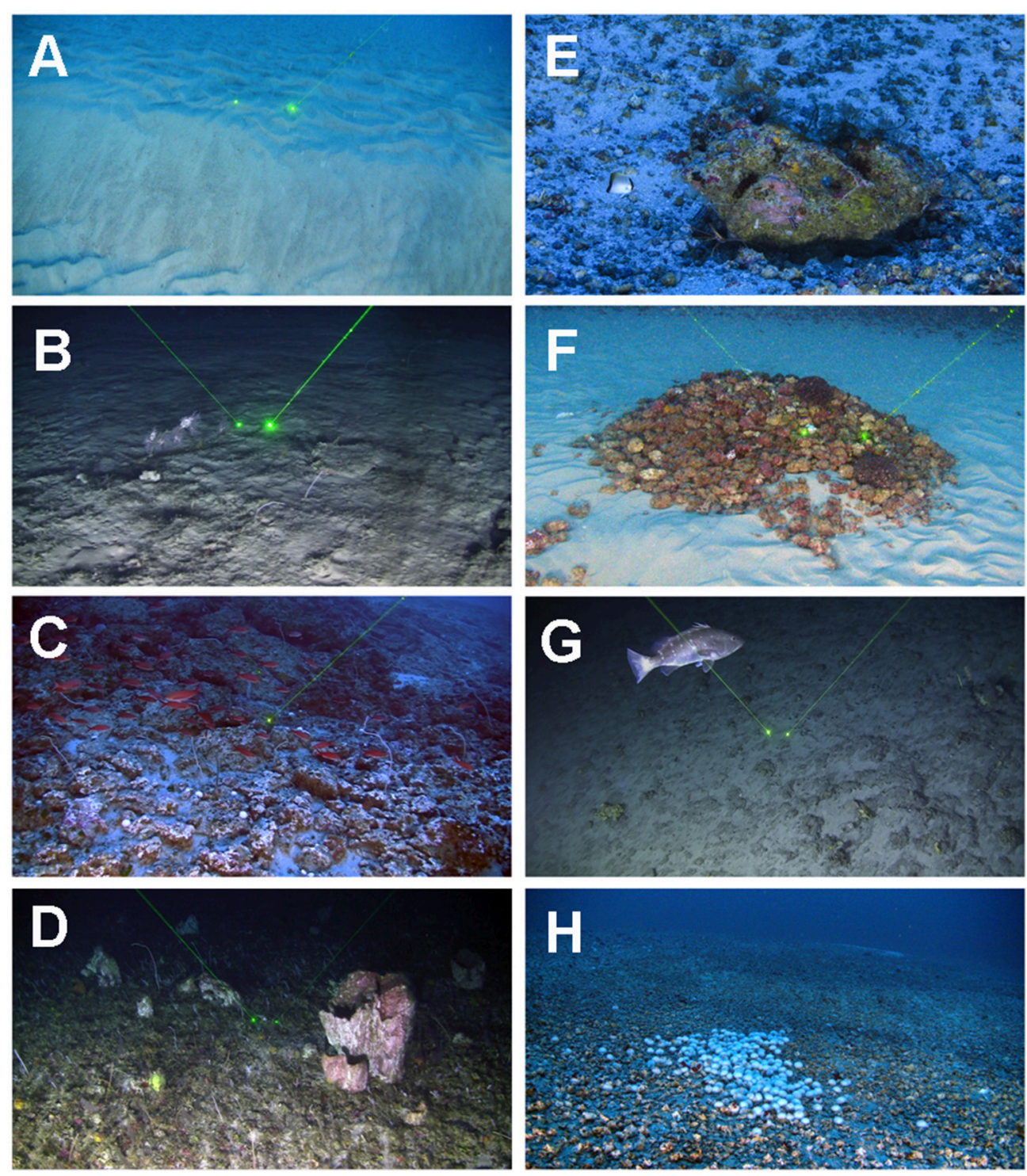

FIGURE 1 | Geodiversity and biodiversity of the GARS. Major structures along the inner and outer shelves. (A) Sand dunes in the shallowest portion of the reef (60-70 m), (B) Reef covered by sediments between 70 and $80 \mathrm{~m}$ depth, (C) Diverse reef community with schools of Paranthias furcifer and bottom dominated by live crustose calcareous algae and black corals at $130 \mathrm{~m}$ depth, (D) Deepest portion of the GARS (220 m) with nearly $100 \%$ of live benthic coverage (mostly sponges, octocorals and black corals), (E) A cleaning station of the Peppermint shrimp Lysmata grabhami at $110 \mathrm{~m}$ depth, (F) Rhodolith mound built by the Sand tilefish Malacanthus plumieri at $130 \mathrm{~m}$ depth, (G) A large individual (>60 cm Total Length) of the commercially important and threatened snowy grouper Hyporthodus niveatus at $190 \mathrm{~m}$ depth and $\mathbf{( H )}$ an urchin barren at $130 \mathrm{~m}$ depth. Laser scale: $20 \mathrm{~cm}$.

Carbonate budget studies have demonstrated that accretion and erosion are highly variable in space and time, with many shallow reefs with small or zero net reef growth. In addition, large reef systems may show net accretion or erosion in different areas and/or periods depending on different biotic (e.g., bioerosion rates) and abiotic factors (e.g., wave intensity) (Grigg, 1998; Glynn and Manzello, 2015). Thus, additional studies are needed to understand carbonate budget dynamics within the GARS.

Despite our limited knowledge of the GARS (by our new approximation, less than $5 \%$ of the reef area has been surveyed so far), the region is coveted by large oil and gas companies (e.g., BHP-Billiton, Queiroz Galvão, Ecopetrol, Total, BP, and Petrobras) (see blocks in Figure 2). Oil exploration within the GARS poses serious threats to the biodiversity and sustainability of the region and the minimal data attained so far indicate that precaution is needed before starting any activity with great potential for reef degradation. For example, an oil spill in the Gulf of Mexico caused by the explosion of the BP-operated Deepwater Horizon (DWH) offshore oil rig led to a large-scale environmental catastrophe, largely impacting reefs and rhodolith beds (Goodbody-Gringley 


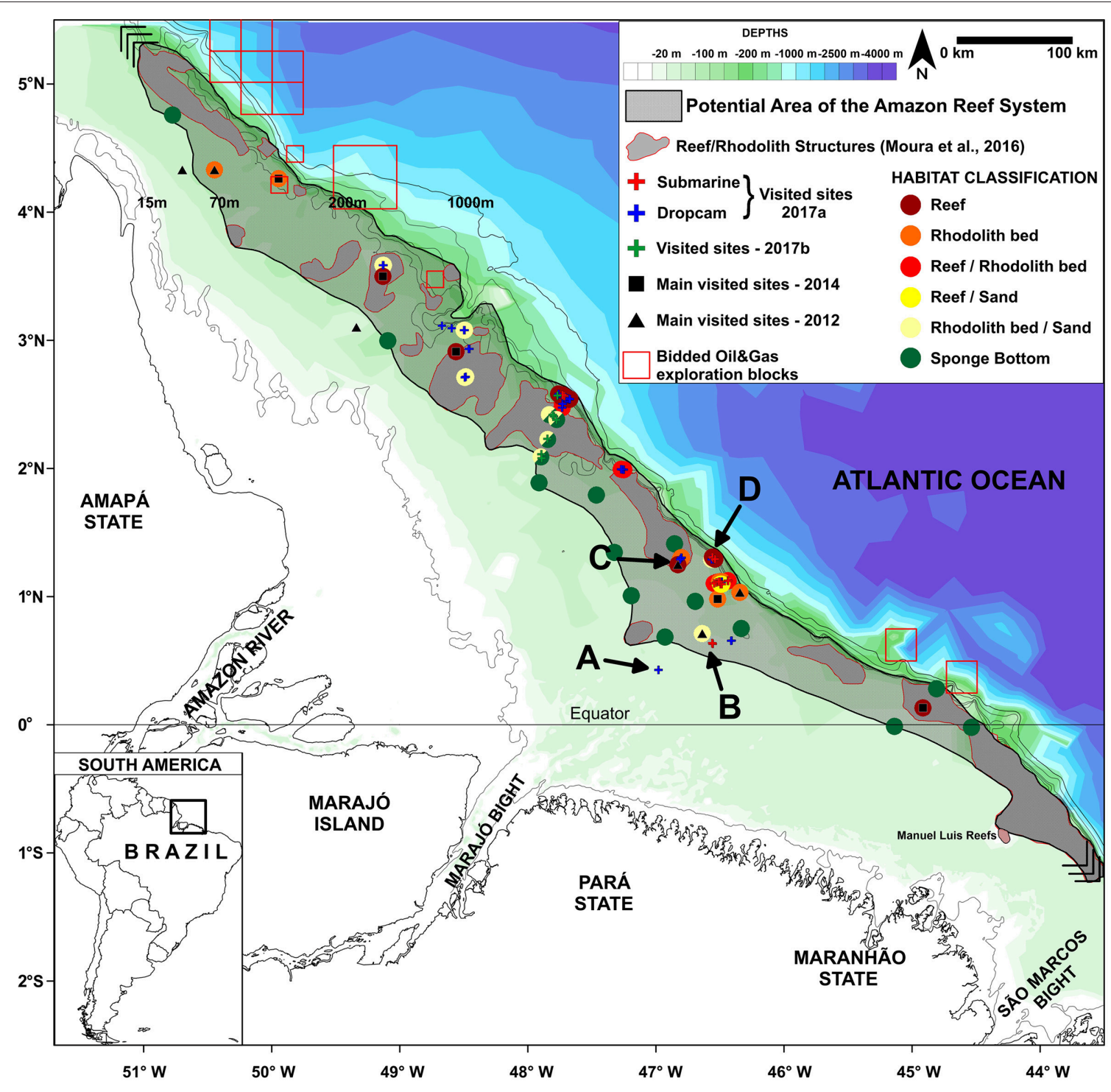

FIGURE 2 | Map of the Great Amazon Reef System (GARS) showing sampling sites. The gray area denotes the potential area covered by mesophotic reefs $\left(56,000 \mathrm{~km}^{2}\right)$. Letters A-D correspond to sites in which images depicted in Figure $\mathbf{1}$ (showing typical features across a $70-220 \mathrm{~m}$ depth gradient) are given.

et al., 2013; Krayesky-Self et al., 2017). The use of oil dispersant to prevent floating oil from reaching the shore caused even more damage to reef communities in the Gulf of Mexico, as the widely used dispersant (Corexit ${ }^{\circledR}$ ) causes oil to sink, suffocating benthic communities, as well as decreased coral larvae settlement and survival (GoodbodyGringley et al., 2013). Previous time-series studies performed in the GARS demonstrate current velocities below sea surface of $\sim 0.3-1.5 \mathrm{~m} . \mathrm{s}^{-1}$ close to the areas of oil exploration, indicating rapid spread may occur in the event of an oil spill (Geyer et al., 1991; Fontes et al., 2008).

Such as mesophotic reefs elsewhere, the GARS can be considered a biodiversity refuge in periods of climate changes that are extirpating shallow reefs (reseeding or deep reef refuge hypothesis; Bongaerts et al., 2010, 2017). Data from the present survey suggest that the reef size, contiguousness, and the biodiversity associated with the GARS could be far greater than realized. Our perspective is that broad baseline studies (i.e., geophysical, geological, physical, chemical, and biological oceanographic surveys) are urgently required for better understanding the GARS and for applying a systematic conservation planning approach for the creation of a network of Marine Protected Areas (MPAs). Precautionary conservation measures should be adopted to avoid drilling, mining, and unregulated fisheries in sensitive areas and a comprehensive baseline assessment is needed for future evaluations of impacts in the case of oil spills. In summary, broader studies and the creation of a network of MPAs may help to reconcile extractive activities 
(mining, fishing) with effective biodiversity conservation in the GARS.

\section{AUTHOR CONTRIBUTIONS}

RF-F, NA, ES, and FT delineated the study. RF-F, NA, ES, $\mathrm{JH}, \mathrm{KL}, \mathrm{AV}$, and FT collected the data. CO processed and analyzed the MODIS Ocean Color data. RF-F, $\mathrm{NA}, \mathrm{ES}, \mathrm{JH}, \mathrm{KL}, \mathrm{ND}, \mathrm{AV}, \mathrm{RB}, \mathrm{CR}, \mathrm{CO}, \mathrm{CT}$, and FT contributed with resources, analyzed the data and wrote the manuscript.

\section{REFERENCES}

Bongaerts, P., Ridgeway, T., Sampayo, E. M., and Hoegh-Guldberg, O. (2010). Assessing the 'deep reef refugia' hypothesis: focus on Caribbean reefs. Coral Reefs 29, 309-327. doi: 10.1007/s00338-009-0581-x

Bongaerts, P., Riginos, C., Brunner, R., Englebert, N., Smith, S. R., and HoeghGuldberg, O. (2017). Deep reefs are not universal refuges: reseeding potential varies among coral species. Sci. Adv. 3:e1602373. doi: 10.1126/sciadv.1602373

Bosence, D. W. J. (1983). Coralline algal reef frameworks. J. Geol. Soc. 140, 365-376. doi: 10.1144/gsjgs.140.3.0365

Collette, B. B., and Ruetzler, K. (1977). Reef fishes over sponge bottoms off the mouth of the Amazon River. Proc. Int. Coral Reef Symp. 3, 305-310.

Cordeiro, R. T., Neves, B. M., Rosa-Filho, J. S., and Pérez, C. D. (2015). Mesophotic coral ecosystems occur offshore and north of the Amazon River. Bull. Mar. Sci. 91, 491-510. doi: 10.5343/bms.2015.1025

Davies, P. J., Braga, J. C., Lund, M., and Webster, J. M. (2004). Holocene deep water algal buildups on the eastern Australian shelf. Palaios 19, 598-609. doi: 10.1669/ 0883-1351(2004)019<0598:HDWABO >2.0.CO;2

Earle, S. (2010). Sylvia Earle on protecting our seas. Nature 465:165. doi: $10.1038 / 465165 a$

Figueiredo, M. A. O., Coutinho, R., Villas-Bôas, A. B., Tâmega, F. T. S., and Mariath, R. (2012). Deep-water rhodoliths productivity and growth in the southwestern Atlantic. J. Appl. Phycol. 24, 487-493. doi: $10.1007 / \mathrm{s} 10811-012-9802-8$

Floeter, S. R., Rocha, L. A., Robertson, D. R., Joyeux, J. C., Smith-Vaniz, W. F., Wirtz, P., et al. (2008). Atlantic reef fish biogeography and evolution. J. Biogeogr. 35, 22-47. doi: 10.1111/j.1365-2699.2007.01790.x

Fontes, R. F. C., Castro, B. M., and Beardsley, R. C. (2008). Numerical study of circulation on the inner Amazon Shelf. Ocean Dynamics 58, 187-198. doi: 10.1007/s10236-008-0139-4

Francini-Filho, R. B., Coni, E. O., Meirelles, P. M., Amado-Filho, G. M., Thompson, F. L., Pereira-Filho, G. H., et al. (2013). Dynamics of coral reef benthic assemblages of the Abrolhos Bank, eastern Brazil: inferences on natural and anthropogenic drivers. PLOS ONE 8:e54260. doi: 10.1371/journal.pone. 0054260

Geyer, W. R., Beardsley, R. C., Candela, J., Castro, B. M., Legeckis, R. V., Lentz, S. J., et al. (1991). The physical oceanography of the Amazon outflow. Oceanography 4, 8-14. doi: 10.5670/oceanog. 1991.15

Gherardi, D. F. M., and Bosence, D. W. J. (2001). Composition and community structure of the coralline algal reefs from Atol das Rocas, South Atlantic, Brazil. Coral Reefs 19, 205-219. doi: 10.1007/s003380000100

Glynn, P. W., and Manzello, D. P. (2015). "Bioerosion and coral reef growth: a dynamic balance," in Coral Reefs in the Anthropocene, ed C. Birkeland (Dordrecht: Springer), 67-97.

Goodbody-Gringley, G., Wetzel, D. L., Gillon, D., Pulster, E., Miller, A., and Ritchie, K. B. (2013). Toxicity of deepwater horizon source oil and the chemical dispersant, Corexit ${ }^{\circledR}$ 9500, to coral larvae. PLoS ONE 8:e45574. doi: 10.1371/journal.pone.0045574

Grigg, R. W. (1998). Holocene coral reef accretion in Hawaii: a function of wave exposure and sea level history. Coral Reefs 17, 263-272. doi: $10.1007 / \mathrm{s} 003380050127$

\section{FUNDING}

Coordenação de Aperfeiçoamento de Pessoal de Nível Superior (CAPES) through its IODP/CAPES-Brasil program, Conselho Nacional de Desenvolvimento Científico e Tecnológico (CNPq).

\section{ACKNOWLEDGMENTS}

We thank the Greenpeace Esperanza and Nuytco crew for the help during the cruise and dives. RF-F, NA, ES, CR, CT, and $\mathrm{FT}$ are $\mathrm{CNPq}$ research fellows. $\mathrm{CO}$ was supported by an IODP/CAPES fellowship.

Krayesky-Self, S., Schmidt, W. E., Phung, D., Henry, C., Sauvage, T., Camacho, O., et al. (2017). Eukaryotic life inhabits rhodolith-forming coralline algae (Hapalidiales, Rhodophyta), remarkable marine benthic microhabitats. Sci. Rep. 7:45850. doi: 10.1038/srep45850

Lee, Z.., Carder, K. L., and Arnone, R. (2002). Deriving quasi-inherent optical properties from water color: a multiband quasi-analytical algorithm for optically deep waters. Appl. Opt. 41, 5755-5772. doi: 10.1364/AO.41. 005755

Lee, Z.-P., Du, K.-P., and Arnone, R. (2005). A model for the diffuse attenuation coefficient of downwelling irradiance. J. Geophys. Res. 110:C02016. doi: 10.1029/2004JC002275

Lesser, M. P., Slattery, M., and Leichter, J. J., (2009). Ecology of mesophotic coral reefs. J. Exp. Mar. Biol. Ecol. 375, 1-8. doi: 10.1016/j.jembe.2009.05.009

Littler, M. M., Littler, D. S., Blair, S. M., and Norris, J. N. (1986). Deep-water plant communities from an uncharted seamount off San Salvador Island, Bahamas: distribution, abundance, and primary productivity. Deep Sea Res. A 33, 881-892. doi: 10.1016/0198-0149(86) 90003-8

Moura, R. L., Amado-Filho, G. M., Moraes, F. C., Brasileiro, P. S., Salomon, P. S., Mahiques, M. M., et al. (2016). An extensive reef system at the Amazon River mouth. Sci. Adv. 2:e1501252. doi: 10.1126/sciadv.1501252

Riul, P., Targino, C. H., Farias, J. N., Visscher, P. T., and Horta, P. A. (2008). Decrease in Lithothamnion sp. (Rhodophyta) primary production due to the deposition of a thin sediment layer.J. Mar. Biol. Assoc. U.K. 88, 17-19. doi: $10.1017 /$ S0025315408000258

Rocha, L. A. (2003). Patterns of distribution and processes of speciation in Brazilian reef fishes. J. Biogeogr. 30, 1161-1171. doi: 10.1046/j.1365-2699.2003.00900.x

Rosa, M. R., Alves, A. C., Medeiros, D. V., Coni, E. O. C., Ferreira, C. M., Ferreira, B. P., et al.(2016) Mesophotic reef fish assemblages of the remote St. Peter and St. Paul's Archipelago, Mid-Atlantic Ridge, Brazil. Coral Reefs 35, 113-123. doi: 10.1007/s00338-015-1368-x

Villas-Bôas, A. B., Figueiredo MA de, O., and Villaça, R. C. (2005). Colonization and growth of crustose coralline algae (Corallinales, Rhodophyta) on the Rocas Atoll. Braz. J. Oceanogr. 53, 147-156. doi: 10.1590/S1679-87592005000 200005

Conflict of Interest Statement: The handling Editor declared a past co-authorship with one of the authors FT.

The other authors declare that the research was conducted in the absence of any commercial or financial relationships that could be construed as a potential conflict of interest.

Copyright @ 2018 Francini-Filho, Asp, Siegle, Hocevar, Lowyck, D’Avila, Vasconcelos, Baitelo, Rezende, Omachi, Thompson and Thompson. This is an open-access article distributed under the terms of the Creative Commons Attribution License (CC $B Y)$. The use, distribution or reproduction in other forums is permitted, provided the original author(s) and the copyright owner are credited and that the original publication in this journal is cited, in accordance with accepted academic practice. No use, distribution or reproduction is permitted which does not comply with these terms. 